Research Journal of Medical Sciences 4 (3): 199-203, 2010

ISSN: $1815-9346$

(C) Medwell Journals, 2010

\title{
Evaluation of DNA Fragmentation in Leukocytes of Type I Diabetic Patients
}

\author{
Magdy A. Ghoneim and Abdulrahman L. Al-Malki \\ Department of Biochemistry, Faculty of Science, King Abdulaziz University, \\ P.O. Box 80203, Jeddah 21589, Kingdom of Saudi Arabia
}

\begin{abstract}
The current study was carried out to evaluate the degree of DNA fragmentation that might happen in leukocytes due to diabetes mellitus. Twenty blood samples were obtained from fasting normal and type I diabetic patients subjected to regular analysis at Jeddah Regional Laboratory. The plasma samples are evaluated for blood glucose level while leukocytes are used for determination of DNA fragmentation by both spectrophotometric and electrophoretic methods. Samples of non-diabetic subjects revealed normal blood glucose levels $<120 \mathrm{mg} \mathrm{dL}^{-1}$. At the same time, samples of diabetic patients showed significant hyperglycemia $>120 \mathrm{mg} \mathrm{dL}{ }^{-1}$. The results of determination of DNA fragmentation levels showed high percentages (as measured by OD) of diabetic samples in comparison to the samples of normal patients. The results of spectrophotometric determination are confirmed by determination of DNA fragmentations in leukocytes by agarose gel electrophoresis and image analysis of fragmented DNA where they are increased in diabetic patients. It is concluded that type I diabetes has a deleterious effect on DNA which may be due to production of reactive free radicals. Therefore, it is recommended that diabetic patients should be advised to administer antioxidants in their treatment.
\end{abstract}

Key words: DNA fragmentation, diabetes, type I, leukocytes, ROS, antioxidants

\section{INTRODUCTION}

Diabetes mellitus, often referred to simply as diabetes is a syndrome of disordered metabolism usually due to a combination of hereditary and environmental causes, resulting in abnormally high blood sugar levels (hyperglycemia) (Tierney et al., 2002). Diabetes mellitus refers to the group of diseases that lead to high blood glucose levels due to defects in either insulin secretion or insulin action in the body (Rother, 2007). Diabetes develops due to a diminished production of insulin (type 1) or resistance to its effects (in type 2 and gestational) (WHO, 1999; Department of Noncommunicable Disease Surveillance). Diabetic Ketoacidosis (DKA) is an acute and dangerous complication results from low insulin levels that cause the liver to turn to fat for fuel (i.e., ketosis). Ketoacidosis (much more common in type 1 diabetes than type 2) can easily become severe enough to cause hypotension, shock and death.

Adler et al. (2000) stated that chronic elevation of blood glucose level leads to damage of blood vessels (angiopathy). The endothelial cells lining the blood vessels take in more glucose than normal, since they don't depend on insulin. They then form more surface glycoproteins than normal and cause the basement membrane to grow thicker and weaker. In diabetes, the resulting problems are grouped under microvascular disease (due to damage to small blood vessels) and macrovascular disease (due to damage to the arteries). Carotid artery stenosis does not occur more often in diabetes and there appears to be a lower prevalence of abdominal aortic aneurysm. However, diabetes does cause higher morbidity, mortality and operative risks with these conditions (Weiss and Sumpio, 2006).

Diabetic encephalopathy (Aristides and Rayaz, 2007) is the increased cognitive decline and risk of dementia observed in diabetes. Various mechanisms are proposed including alterations to the vascular supply of the brain and the interaction of insulin with the brain itself (Gispen and Biessels, 2000).

As a result of these complications, many literatures have concluded that diabetes may have a suspected effect on DNA level of the cells (Maruo et al., 2001; Honma et al., 2003; Kumar et al., 2007; Xu et al., 2008). Therefore this study is planned to focus on estimation of the level of DNA fragmentation in blood cells of type I diabetic patients to through more light on the effect of

Corresponding Author: Magdy A. Ghoneim, Department of Biochemistry, Faculty of Science, King Abdulaziz University, P.O. Box 80203 , Jeddah 21589, Kingdom of Saudi Arabia 
diabetes on the DNA level of blood in relation to normal subjects. This is trying to find a correlation between level of DNA fragmentation and progress of type I diabetes.

\section{MATERIALS AND METHODS}

Blood samples: Blood samples are collected from fasting normal and diabetic subjects admitted to Jeddah Regional Laboratory at Al Mahjar district of Jeddah city, Kingdom of Saudi Arabia after obtaining of informed consents from these subjects. The patients are selected to have diabetes mellitus type I and do not suffer any other complications according to their case history and clinical investigations. About 20 blood samples are collected from each group; part is delivered into fluoride-contained tubes and the other into EDTA-vacuum tanners then gently mixed. Samples of diabetic group are obtained on fasting state and before their administering the insulin treatment. The samples are then delivered directly to the faculty laboratory for examination. Samples are centrifuged for separation of fluorinated plasma for sugar determination and the other samples are used for separation of the buffy coat layer.

Determination of blood glucose level: Fasting blood sugar of obtained plasma samples are determined by chemical auto analyzer Glu3 (Beckman cX3, USA).

Determination of DNA fragmentation level: The level of DNA fragmentation in leukocytes of both control normal and diabetic samples is estimated according to the method of (Perandones et al., 1993). In brief, $0.10 \mathrm{~mL}$ buffy coat layer of blood is suspended in $2 \mathrm{~mL}$ lysis buffer I (Tris-EDTA and Triton X-100) then kept on ice for $15 \mathrm{~min}$. then centrifuged for $20 \mathrm{~min}$ at $27,000 \mathrm{~g}$ to separate high-molecular-weight chromatin from cleavage products. About $2 \mathrm{~mL}$ of buffer II (Tris-EDTA) is added to the pellet and re-centrifuged again. Supernatants of both centrifugations are collected together. Diphenylamine reagent is added to a part of the supernatant and to pellet of each sample and incubated at $37^{\circ} \mathrm{C}$ overnight. Optical density is measured at $578 \mathrm{~nm}$ against blank reagent. Percentage of DNA fragmentation level is calculated from the following equation:

$$
\begin{gathered}
\text { Percentage of DNA fragmentation }=\frac{\text { OD of supernatant }}{\text { OD of pellet }+} \times 100 \\
\text { OD of supernatant }
\end{gathered}
$$

Agarose gel electrophoresis: DNA of another part of supernatant is ethanol precipitated and subjected to electrophoresis using $2 \%$ agarose according to Sambrook et al. (1989). One ug DNA of some random samples from each group is loaded into the gel. Hae III digest of Lambda phage DNA is used as a marker. The gel is photographed under UV transilluminator using a digital camera.

Image and statistical analysis: Significance of the differences between control and diabetic groups are statistically calculated by using student t-test at $\mathrm{p}<0.05$ according to Snedecor and Cochran (1990). Photo of electrophoresis pattern is analyzed using GelPro software (Media Cybernetics Inc., USA) for determination of molecular weight and amount of fragmented DNA.

\section{RESULTS AND DISCUSSION}

It is shown from the obtained results of the present study (Table 1) that samples of non-diabetic subjects revealed normal blood glucose levels $<120 \mathrm{mg} \mathrm{dL}^{-1}$. At the same time, samples of diabetic patients showed significant high levels of blood glucose $>120 \mathrm{mg} \mathrm{dL}^{-1}$. These values of blood glucose are considered in line with the limits of diabetes (WHO, 1999). Hyperglycemia is a profound feature of diabetes that develops either due to a diminished production of insulin (type 1) or resistance to its effects (type 2 and gestational). However, samples of diabetic patients are categorized into type 1 according to their case history and analysis data.

DNA damage may be associated with type 2 Diabetes Mellitus (T2DM) and its complications mainly through oxidative stress. Blasiak et al. (2004) found that the levels of basal endogenous and oxidative DNA damage in diabetes patients were higher than in control subjects. Diabetes patients displayed higher susceptibility to hydrogen peroxide and doxorubicin and decreased efficacy of repairing DNA damage induced by these

\begin{tabular}{lcc}
\multicolumn{3}{l}{ Table 1: Showing blood glucose level in obtained blood samples $\left(\mathrm{mg} \mathrm{dL}^{-1}\right)$} \\
\hline No. of sample & Normal samples & Diabetic samples \\
\hline 1 & 110 & 231 \\
2 & 90 & 250 \\
3 & 112 & 223 \\
4 & 107 & 242 \\
5 & 111 & 273 \\
6 & 109 & 198 \\
7 & 119 & 291 \\
8 & 88 & 235 \\
9 & 115 & 186 \\
10 & 118 & 243 \\
11 & 85 & 288 \\
12 & 103 & 222 \\
13 & 114 & 190 \\
14 & 121 & 188 \\
15 & 114 & 178 \\
16 & 118 & 227 \\
17 & 106 & 298 \\
18 & 91 & 310 \\
19 & 105 & 239 \\
20 & 110 & 179 \\
Mean \pm SE & $107.3 \pm 2.4$ & $234.6 \pm 9.2^{*}$ \\
\hline
\end{tabular}


Res. J.Med. Sci., 4 (3): 199-203, 2010

Table 2: Showing percentages of DNA fragmentation (\%) in leukocytes

\begin{tabular}{lcc}
\hline No. of sample & Normal samples & Diabetic samples \\
\hline 1 & 3.35 & 9.11 \\
2 & 5.60 & 7.56 \\
3 & 4.81 & 5.89 \\
4 & 3.09 & 8.90 \\
5 & 4.12 & 8.32 \\
6 & 2.38 & 14.21 \\
7 & 3.45 & 11.67 \\
8 & 3.70 & 9.02 \\
9 & 2.66 & 10.99 \\
10 & 2.88 & 11.39 \\
11 & 2.87 & 9.76 \\
12 & 4.76 & 8.95 \\
13 & 4.55 & 8.57 \\
14 & 3.97 & 12.31 \\
15 & 5.37 & 12.66 \\
16 & 3.45 & 13.54 \\
17 & 4.31 & 14.10 \\
18 & 3.46 & 9.15 \\
19 & 2.98 & 7.43 \\
20 & 2.44 & 13.56 \\
Mean \pm SE & $3.71 \pm 0.21$ & $10.35 \pm 0.55$ \\
\hline
\end{tabular}

agents than healthy controls. The results suggest that type I diabetes mellitus may be associated with the elevated level of oxidative DNA damage in blood leukocytes. Similar findings were reported in diabetic females by Lima et al. (2008). The results of determination of DNA fragmentation levels of Table 2 showed high percentages (as measured by OD) of diabetic samples in comparison to the samples of normal patients.

The results of spectrophotometric determination are supported by determination of DNA fragmentations using agarose electrophoresis and image analysis where they are increased in diabetic patients. Similar findings are also obtained by Bagatini et al. (2008) in Type 2 diabetic patients undergoing hemodialysis. Reactive Oxygen Species (ROS) is a collective term which encompasses all highly reactive oxygen containing molecules.

Free radicals are electrically charged molecules (having unpaired electron) which causes them to seek out and capture electrons from other substances in order to neutralize themselves. Chronic diabetes is one of the causes of ROS formation (Lodovici et al., 2008). Cellular response to ROS is in the form of severe metabolic dysfunction, peroxidation of membrane lipids, oxidative protein damage, alteration of cytoplasmic and nuclear signal transduction and DNA damage (Ishii et al., 1996).

DNA ladder of the samples (Fig. 1 and Table 3) revealing high fragmentations as a result of diabetes either in relation to molecular weight or amount of fragmented DNA. These results are discussed by many previous literatures in other tissues. Smyth et al. (2008) suggested that common biologic mechanisms such as autoimmunity-related tissue damage and intolerance to dietary antigens may be etiologic features of both
Table 3: Showing molecular weights (bp) and amounts (ng) of DNA ladder of analyzed samples

\begin{tabular}{|c|c|c|c|c|c|}
\hline $\begin{array}{l}\text { No. of } \\
\text { lane }\end{array}$ & $\begin{array}{c}\text { Mol. W. } \\
\text { bp }\end{array}$ & $\begin{array}{l}\text { Amount } \\
\mathrm{Ng}\end{array}$ & $\begin{array}{c}\text { No. of } \\
\text { lane }\end{array}$ & $\begin{array}{c}\text { Mol. W. } \\
\text { bp }\end{array}$ & $\begin{array}{c}\text { Amount } \\
\text { ng }\end{array}$ \\
\hline \multirow[t]{2}{*}{2} & - & - & 8 & 200 & 97 \\
\hline & & & & 400 & 141 \\
\hline \multirow[t]{2}{*}{3} & - & - & 9 & 200 & 109 \\
\hline & & & & 400 & 158 \\
\hline \multirow[t]{3}{*}{4} & 400 & 163 & 10 & 200 & 114 \\
\hline & & & & 400 & 174 \\
\hline & & & & 800 & 163 \\
\hline \multirow[t]{3}{*}{5} & 400 & 147 & 11 & 200 & 73 \\
\hline & & & & 400 & 160 \\
\hline & & & & 800 & 148 \\
\hline \multirow[t]{3}{*}{6} & 400 & 129 & 12 & 200 & 108 \\
\hline & & & & 400 & 152 \\
\hline & & & & 800 & 160 \\
\hline \multirow[t]{6}{*}{7} & 200 & 73 & 13 & 200 & 131 \\
\hline & 600 & 126 & & 400 & 166 \\
\hline & & & & 800 & 178 \\
\hline & & & 14 & 200 & 114 \\
\hline & & & & 400 & 188 \\
\hline & & & & 800 & 190 \\
\hline
\end{tabular}

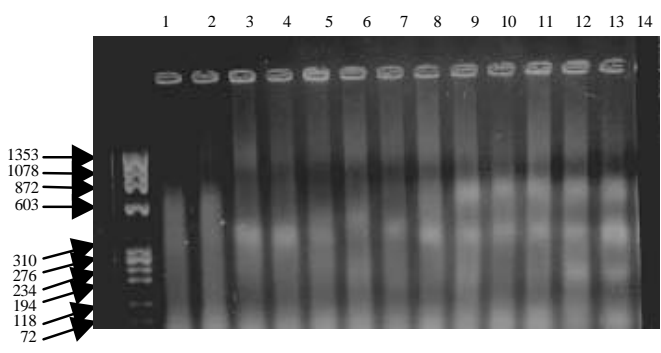

Fig. 1: Showing electrophoresis pattern of recovered DNA fragments of leukocytes. Lane 1: Hae III digest of Phage DNA; lanes 2-7: DNA fragments of normal samples; lanes 8-14: DNA fragments of diabetic samples

diseases. Takasu et al. (1991) stated that DNA fragmentation supposedly results from the accumulation of superoxide or hydroxyl radicals. Results of Kumar et al. (2007) suggested the potential of resveratrol in treatment of diabetic neuropathy and its protective effect may be mediated through reduction in oxidative stress and DNA fragmentation.

Maruo et al. (2001) showed that some cells in the stratum granulosum exhibited a sign of DNA fragmentation when laminar splitting took place in the vital cell layer. At the same time, Fidan and Dundar (2008) found that mononuclear leukocyte DNA damage, plasma malondialdehyde and plasma protein carbonyl levels were significantly lower in the groups treated with antidiabetic plants. The genomic damage evident in spermatozoa of type 1 diabetics may have important implications for their fertility and the outcome of pregnancies fathered by these individuals (Agbaje et al., 2008). Sliwinska et al. (2008) 
stated also that diabetic patients had increased level of oxidative DNA damage and decreased effectiveness of DNA repair. Simone et al. (2008) found that hyperglycemia in type 1 diabetes and treatment of proximal tubular epithelial cells with high glucose leads to phosphorylation/inactivation of tuberin and downregulation of OGG1 via a redox-dependent activation of Akt in renal tubular epithelial cells. This signaling cascade provides a mechanism of oxidative stress-mediated DNA damage in diabetes.

\section{CONCLUSION}

In this study, diabetic patients (in special reference to type 1) may be exposed to a certain degree of DNA fragmentation depending on the severity and chronicity of the case as may be a result of ROS generation. Therefore, these patients may be recommended to administer some sort of antioxidants as a prophylactic measure

\section{REFERENCES}

Adler, A.I., I.M. Stratton, H.A.W. Neil, J.S. Yudkin and D.R. Matthews et al., 2000. Association of systolic blood pressure with macrovascular and microvascular complications of type 2 diabetes rospective observational study. Br. Med. J., 321: 412-419.

Agbaje, I.M., C.M. McVicar, B.C. Schock, N. McClure, A.B. Atkinson, D. Rogers and S.E. Lewis, 2008. Increased concentrations of the oxidative DNA adduct 7,8-dihydro-8-oxo-2-deoxyguanosine in the germ-line of men with type 1 diabetes. Reprod. Biomed. Online, 16: 401-409.

Aristides, V. and A.M. Rayaz, 2007. Diabetic Neuropathy: Clinical Management (Clinical Diabetes). 2nd Edn., Humana Press, New York, pp: 188-198.

Bagatini, P.B., R.P. Palazzo, M.T. Rodrigues, C.H. Costa and S.W. Maluf, 2008. Induction and removal of DNA damage in blood leukocytes of patients with type 2 diabetes mellitus undergoing hemodialysis. Mutat. Res., 657: 111-115.

Blasiak, J., M. Arabski, R. Krupa, K. Wozniak and M. Zadrozny et al., 2004. DNA damage and repair in type 2 diabetes mellitus. Mutat. Res., 554: 297-304.

Fidan, A.F. and Y. Dundar, 2008. The effects of Yucca schidigera and Quillaja saponaria on DNA damage, protein oxidation, lipid peroxidation and some biochemical parameters in streptozotocin-induced diabetic rats. J. Diabetes Complications, 22: 348-356.
Gispen, W.H. and G.J. Biessels, 2000. Cognition and synaptic plasticity in diabetes mellitus. Trends Neurosci., 23: 542-549.

Honma, H., J.L. Podratz and A.J. Windebank, 2003. Acute glucose deprivation leads to apoptosis in a cell model of acute diabetic neuropathy. J. Peripheral Nervous Syst., 8: 65-74.

Ishii, N., Z. Ogawa, K. Suzuki, K. Numakami, T. Saruta and H. Itoh, 1996. Glucose loading induces DNA fragmentation in rat proximal tubular cells. Metabolism, 45: 1348-1353.

Kumar, A., R.K. Kaundal, S. Iyer and S.S. Sharma, 2007. Effects of resveratrol on nerve functions, oxidative stress and DNA fragmentation in experimental diabetic neuropathy. Life Sci., 80: 1236-1244.

Lima, P.H., D.C. Damasceno, Y.K. Sinzato, de Souza and S. Mda et al., 2008. Levels of DNA damage in blood leukocyte samples from non-diabetic and diabetic female rats and their fetuses exposed to air or cigarette smoke. Mutat. Res., 653: 44-49.

Lodovici, M., L. Giovannelli, V. Pitozzi, E. Bigagli, G. Bardini and C.M. Rotella, 2008. Oxidative DNA damage and plasma antioxidant capacity in type 2 diabetic patients with good and poor glycaemic control. Mutat. Res., 638: 98-102.

Maruo, Y., T. Sugimoto, M. Oka, T. Hara and T. Sato, 2001. Accelerated DNA fragmentation of the denturebearing mucosal epithelium in an animal model of diabetes. J. Oral Rehabil., 28: 393-399.

Perandones, C.E., V.A. Liiera, D. Peckham, L.L. Stunz and R.F. Ashman, 1993. Regulation of apoptosis in vitro in mature spleen T-cell. J. Immunol., 151: 3521-3528.

Rother, K.I., 2007. Diabetes treatment-bridging the divide. New Engl. J. Med., 356: 1499-1501.

Sambrook, J., E.R. Fritsch and T. Maniatis, 1989. Molecular cloning: Alaboratory Manual. 2nd Edn., Cold Spring Harbor Laboratory Press, Cold Spring Harbor, NY.

Simone, S., Y. Gorin, C. Velagapudi, H.E. Abboud and S.L. Habib, 2008. Mechanism of oxidative DNA damage in diabetes: Tuberin inactivation and downregulation of DNA repair enzyme 8-oxo-7,8dihydro-2-deoxyguanosine-DNA glycosylase. Diabetes, 57: 2626-2636.

Sliwinska, A., J. Blasiak, J. Kasznicki and J. Drzewoski, 2008. In vitro effect of gliclazide on DNA damage and repair in patients with type 2 diabetes mellitus (T2DM). Chemico Biol. Interact., 173: 159-165.

Smyth, D.J., V. Plagnol, N.M. Walker, J.D. Cooper and $\mathrm{K}$. Downes et al., 2008. Shared and distinct genetic variants in type 1 diabetes and celiac disease. New Engl. J. Med., 359: 2767-2777. 
Snedecor, G.W. and W.G. Cochran, 1990. Statistical Methods. 9th Edn., Oxford and J.B.H. Publishing Co., Oxford.

Takasu, N., I. Komiya, T. Asawa, Y. Nagasawa and T. Yamada, 1991. Streptozocin- and alloxaninduced $\mathrm{H}_{2} \mathrm{O}_{2}$ generation and DNA fragmentation in pancreatic islets. $\mathrm{H}_{2} \mathrm{O}_{2}$ as mediator for DNA fragmentation. Diabetes, 40: 1141-1145.

Tierney, S.J., M.A. McPhee and A. Papadakis, 2002. Current medical Diagnosis and Treatment. Lange Medical books/McGraw-Hill, New York, pp: 1203-1215.
WHO, 1999. Definition, diagnosis and classification of diabetes mellitus and its complications. Part 1: Diagnosis and Classification of Diabetes Mellitus, Geneva. http://whqlibdoc.who.int/hq/1999/WHO NCD_NCS_99.2.pdf.

Weiss, J.S. and B.E. Sumpio, 2006. Review of prevalence and outcome of vascular disease in patients with diabetes mellitus. Eur. J. Vascular Endovascular Sur., 31: $143-150$.

Xu, G., X. Shi, S. Mei, Q. Yao, Q. Weng and C. Wu, 2008. Capillary electrophoresis of oxidative DNA damage. Methods Mol. Biol., 384: 431-440. 